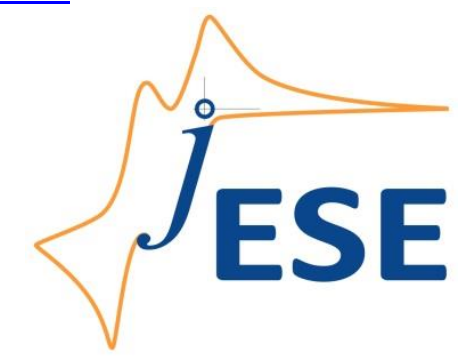

Open Access : : ISSN 1847-9286

www.jESE-online.org

Original scientific paper

\title{
Organic and inorganic compounds as corrosion inhibitors to reduce galvanic effect for the hybrid structure AA2024-CFPR
}

Roy Lopez-Sesenes ${ }^{1, \bigotimes}$, Jose Gonzalo Gonzalez-Rodriguez ${ }^{2}$, José Gerardo Vera-Dimas ${ }^{1}$, Rene Guardian-Tapia ${ }^{2}$ and Luis Cisneros-Villalobos ${ }^{1}$

${ }^{1}$ Universidad Autónoma del Estado de Morelos, Facultad de Ciencias Químicas e Ingeniería, Av. Universidad 1001 Col. Chamilpa,CP. 62209, Cuernavaca Morelos, México

${ }^{2}$ Universidad Autónoma del Estado de Morelos, CIICAp, Av. Universidad 1001 Col. Chamilpa,CP. 62209, Cuernavaca Morelos, México

Corresponding author: ${ }^{\otimes}$ rlopez@uaem.mx

Received: September 29, 2021; Accepted: October 30, 2021; Published: November 13, 2021

\begin{abstract}
The effect of the galvanic corrosion process taking place between aluminium alloy (AA2024-T3) and carbon fiber reinforced plastic (CFRP) immersed in $0.05 \mathrm{M} \mathrm{NaCl}$ was studied using organic and inorganic compounds as corrosion inhibitors. Electrochemical approaches such as electrochemical noise analysis (ENA) and electrochemical impedance spectroscopy (EIS) were carried out to evaluate efficiencies of 1,2,4-triazole $\left(\mathrm{C}_{2} \mathrm{H}_{3} \mathrm{~N}_{3}\right)$ and cerium nitrate hexahydrate $\left(\mathrm{Ce}\left(\mathrm{NO}_{3}\right)_{3} \cdot 6 \mathrm{H}_{2} \mathrm{O}\right)$ as corrosion inhibitors. The highest efficiency was reached for $\mathrm{Ce}\left(\mathrm{NO}_{3}\right)_{3} 6 \mathrm{H}_{2} \mathrm{O}$, with some improvement observed by adding $\mathrm{C}_{2} \mathrm{H}_{3} \mathrm{~N}_{3}$ in a mixed inhibitor solution. The noise resistance $\left(R_{n}\right)$ and polarization resistance $\left(R_{p}\right)$ values calculated from ENA and EIS data showed almost identical behavior with different magnitudes but similar trends. Adsorption isotherm models estimated with fractional surface coverage ( $\theta$ ) parameter were fitted better to Langmuir model for $\mathrm{C}_{2} \mathrm{H}_{3} \mathrm{~N}_{3}$ and Temkin model for $\mathrm{Ce}\left(\mathrm{NO}_{3}\right)_{3} \cdot 6 \mathrm{H}_{2} \mathrm{O}$. The calculated values of Gibbs free energy suggested physisorption and chemisorption as spontaneous interactions between a metal surface and both inhibitors. Energy-dispersive X-ray spectroscopy (EDS) was carried out before and after immersing AA2024-T3 in the electrolyte, identifying rich zones in copper with cerium deposited over it and confirming the presence of rare-earth oxide deposition and oxide film products. The EDS analysis for CFRP revealed the deposition of Ce and Al particles over its surface after immersion in the electrolyte, especially in the areas rich in carbon.
\end{abstract}

Keywords

Electrochemical methods, rare earths, adsorption isotherm, Gibbs free energy, synergistic effect, power spectral density 


\section{Introduction}

Hybrid structures have received great interest from the aerospace industry, especially in cases where a single material can not satisfy structural demands [1]. Materials with a high strength-todensity ratio, such as carbon fiber reinforced plastic (CFRP) and aluminum alloys, are promising candidates for modern aircraft structures since when both are combined, the mechanical properties of a material are improved [2].

Nevertheless, aluminum alloys such as AA2024-T3 in contact with other nobler materials (CFRP) tend to accelerate their electrochemically-driven degradation since they are more active in the galvanic series, showing an anodic behavior [3, 4]. For example, when CFRP is coupled to AA2024-T3 in $\mathrm{NaCl}$ solution, the structural integrity of this last material is compromised since CFRP has an open circuit potential (OCP) around $+0.28 \mathrm{mV}$ (nobler) [5] than AA2024-T3 having OCP around $-500 \mathrm{mV}$ (more active) [6]. Furthermore, AA2024-T3 contains impurities that stimulate the formation of galvanic microcells between the matrix and its intermetallic phases, thus increasing its susceptibility to the degradation processes [7].

A lot of efforts have been focused on analyzing mechanical properties of the hybrid structure AA2024-T3-CFRP, such as tensile and compressive properties, shear strength and damping behavior, and on establishing conditions under which this hybrid material could work without risk of damage during its operating life [8-10]. Based on the latter, Payan et al. did some experiments to find an adequate method for the analysis of the corrosion mechanism of aluminum matrix composite reinforced with graphite fibers, giving quantitative information on the morphology and kinetics of corrosion [11]. Sherif et al. investigated different aluminum-graphite composites, showing the graphite concentration effect in the matrix, and observing an increment in the corrosion rate with reduction of the polarization resistance [12].

It is certainly important to find a way to reduce the effect of the corrosion process that is taking place in these hybrid materials, with the aim to reduce the damage caused by the oxidetion/reduction process. An effective way to resolve it is the utilization of corrosion inhibitors. So far, only a few studies have focused on using inhibitors or their combination for corrosion protection of AA2024-CFRP hybrid structure. Wang et al. have studied the galvanic corrosion resistance of carbon fiber metal laminates (CARALL) with AA2024-T3 and CFRP and proposed a surface treatment technique combining anodizing in sulfuric acid to prevent galvanic corrosion [13]. These authors also showed that the corrosion rate decreased in the presence of the coating over the surface.

The goal of the present work was to reduce the effect of the galvanic corrosion process present in the hybrid structure AA2024-T3-CFRP with corrosion inhibitors. A systematic study of organic and inorganic inhibitors was conducted using a set of complementary electrochemical analyses.

\section{Experimental}

\section{Materials and chemicals}

The nominal composition of AA2024-T3 alloy is listed in Table 1. Several samples were cut to platelets with an exposed area of $2 \mathrm{~cm}^{2}$ with $0.2 \mathrm{~cm}$ thickness. Platelets were ground with emery cloth of 300, 600 and 1000 grit size, degreased with ethanol, washed with distilled water, and dried with dry air. The carbon fiber composite was obtained from a fully cured carbon fiber composite sheet of $0.2 \mathrm{~cm}$ thickness. Samples with a nominal area of $2 \mathrm{~cm}^{2}$ were cut. The carbon fiber composite specimen was prepared to expose one individual region, removing impurities with 320 grade emery paper to improve its conductivity. 
Table 1. Composition of AA2024-T3 aluminum alloy

\begin{tabular}{cccrrrrrrr}
\hline \multicolumn{10}{c}{ Content, wt.\% } \\
\hline $\mathrm{Cu}$ & $\mathrm{Cr}$ & $\mathrm{Fe}$ & $\mathrm{Mg}$ & $\mathrm{Mn}$ & $\mathrm{Si}$ & $\mathrm{Ti}$ & $\mathrm{Zn}$ & Other & $\mathrm{Al}$ \\
\hline $3.8-4.9$ & 0.1 & 0.5 & $1.2-1.8$ & $0.3-0.9$ & 0.5 & 0.15 & 0.25 & 0.15 & Balance \\
\hline
\end{tabular}

Distilled water with a resistivity of $18 \mathrm{M} \Omega \mathrm{cm}$ was used for rinsing and solution preparation. The test solution was naturally aerated at $25^{\circ} \mathrm{C}$. All electrochemical tests were done in $0.05 \mathrm{M} \mathrm{NaCl}$ with stirring at room temperature using a Gill AC computer-controlled potentiostat.

High-grade reagents $\mathrm{Ce}\left(\mathrm{NO}_{3}\right)_{3} \cdot 6 \mathrm{H}_{2} \mathrm{O}$ and $\mathrm{C}_{2} \mathrm{H}_{3} \mathrm{~N}_{3}$ received from Sigma-Aldrich with chemical structures shown in Figure 1 were used as corrosion inhibitors at three concentrations $(0.5,2$ and $10 \mathrm{mM})$ with the aim to observe their protective efficiency against the corrosion process at the metal surface.

a)

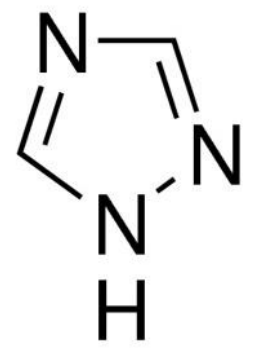

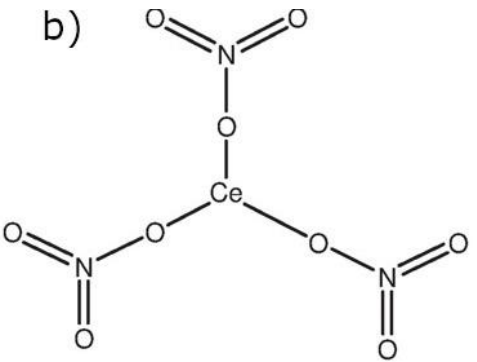

Figure 1. Chemical structures of compounds used as corrosion inhibitors: a) $\mathrm{C}_{2} \mathrm{H}_{3} \mathrm{~N}_{3}$ and b) $\mathrm{Ce}\left(\mathrm{NO}_{3}\right)_{3} \cdot 6 \mathrm{H}_{2} \mathrm{O}$

\section{Electrochemical techniques}

Electrochemical noise analysis (ENA)

ENA technique was carried out recording 1024 points per second each hour for $24 \mathrm{~h}$. Data were recorded simultaneously using a silver-silver chloride $(\mathrm{Ag} / \mathrm{AgCl})$ reference electrode $(\mathrm{RE})$ and $\mathrm{AA204}$ T3 and CFRP in the galvanic couple as working electrode one $\left(W E_{1}\right)$ and working electrode two $\left(W E_{2}\right)$, respectively. The exposed area of each WE was $0.5 \mathrm{~cm}^{2}$. The galvanic couple was closed by a switch before each test, connected via a zero-resistance ammeter (ZRA).

Electrochemical impedance spectroscopy (EIS)

EIS measurements were conducted in a conventional cell of three electrodes, in the following arrangement: $\mathrm{Ag} / \mathrm{AgCl}$ electrode was used as $\mathrm{RE}$, a platinum wire as an auxiliary electrode ( $\mathrm{AE})$, and AA2024-T3 and CFRP in galvanic couple with an exposed area of $0.5 \mathrm{~cm}^{2}$ as working electrodes $\left(\mathrm{WE}_{1}\right.$ or $W E_{2}$ ). EIS was performed at the open circuit potential value with a sinusoidal perturbation of $10 \mathrm{mV}$ RMS (root mean square) amplitude at room temperature, in a frequency range from $30 \mathrm{kHz}$ to $0.01 \mathrm{~Hz}$. The electrochemical cell used for the experiment setup is shown in Figure 2.

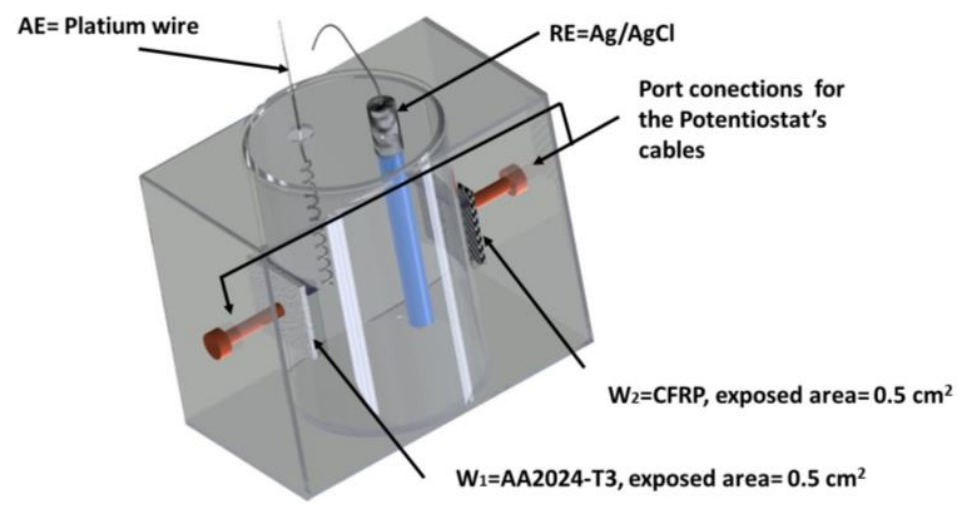

Figure 2. Electrochemical corrosion cell for ENA and EIS measurements 


\section{Surface characterization of corroded surfaces}

Micrographs of corroded AA2024-T3 and CFRP samples in solutions of $0.05 \mathrm{M} \mathrm{NaCl}$ with and without inhibitor, extracted after $24 \mathrm{~h}$ of immersion, were examined with a Tescan Vega3 SB scanning electronic microscope (SEM) with an EDX analyzer.

\section{Results and discussion}

\section{Electrochemical noise analysis (ENA)}

Inhibition effect of 1,2,4-TR.

Figure 3 and 4 shows the current and potential electrochemical noise time series recorded for AA2024-T3-CFRP galvanic couple in $0.05 \mathrm{M} \mathrm{NaCl}$ without and with different concentrations ( 0.5 to $10 \mathrm{mM}$ ) of $\mathrm{C}_{2} \mathrm{H}_{3} \mathrm{~N}_{3}$. The electrochemical current noise (ECN) and the electrochemical potential noise (EPN) plots measured after $1 \mathrm{~h}$ (Figure 3) showed a decrement in their fluctuations when the inhibitor was added into the solution. The single exception is seen for the concentration of $0.5 \mathrm{mM}$, which showed an increment in the current fluctuation from $10^{-5}$ to $5 \times 10^{-5} \mathrm{~mA} \mathrm{~cm}^{-2}$, increasing its frequency domain. The latter is attributed to the formation of a protective film on intermetallic sites, especially where there is copper contained in the sample, forming $\mathrm{Cu}-\mathrm{C}_{2} \mathrm{H}_{3} \mathrm{~N}_{3}$. Moreover, copper reacts with $\mathrm{Cl}^{-}$ ions present in the solution to form $\mathrm{CuCl}^{-}$complexes with $\mathrm{C}_{2} \mathrm{H}_{3} \mathrm{~N}_{3}$ [14], minimizing the oxygen reduction processes at intermetallic particles. Figure 4 shows the current and potential time series recorded after $24 \mathrm{~h}$, where it is evident that the test without inhibitor showed an increment in current fluctuations. For the test with $2 \mathrm{mM} \mathrm{C}_{2} \mathrm{H}_{3} \mathrm{~N}_{3}$ and $10 \mathrm{mM} \mathrm{C}_{2} \mathrm{H}_{3} \mathrm{~N}_{3}$, a diminishing in current fluctuations is appreciable. No change is evident for the test at $0.5 \mathrm{mM} \mathrm{C}_{2} \mathrm{H}_{3} \mathrm{~N}_{3}$.
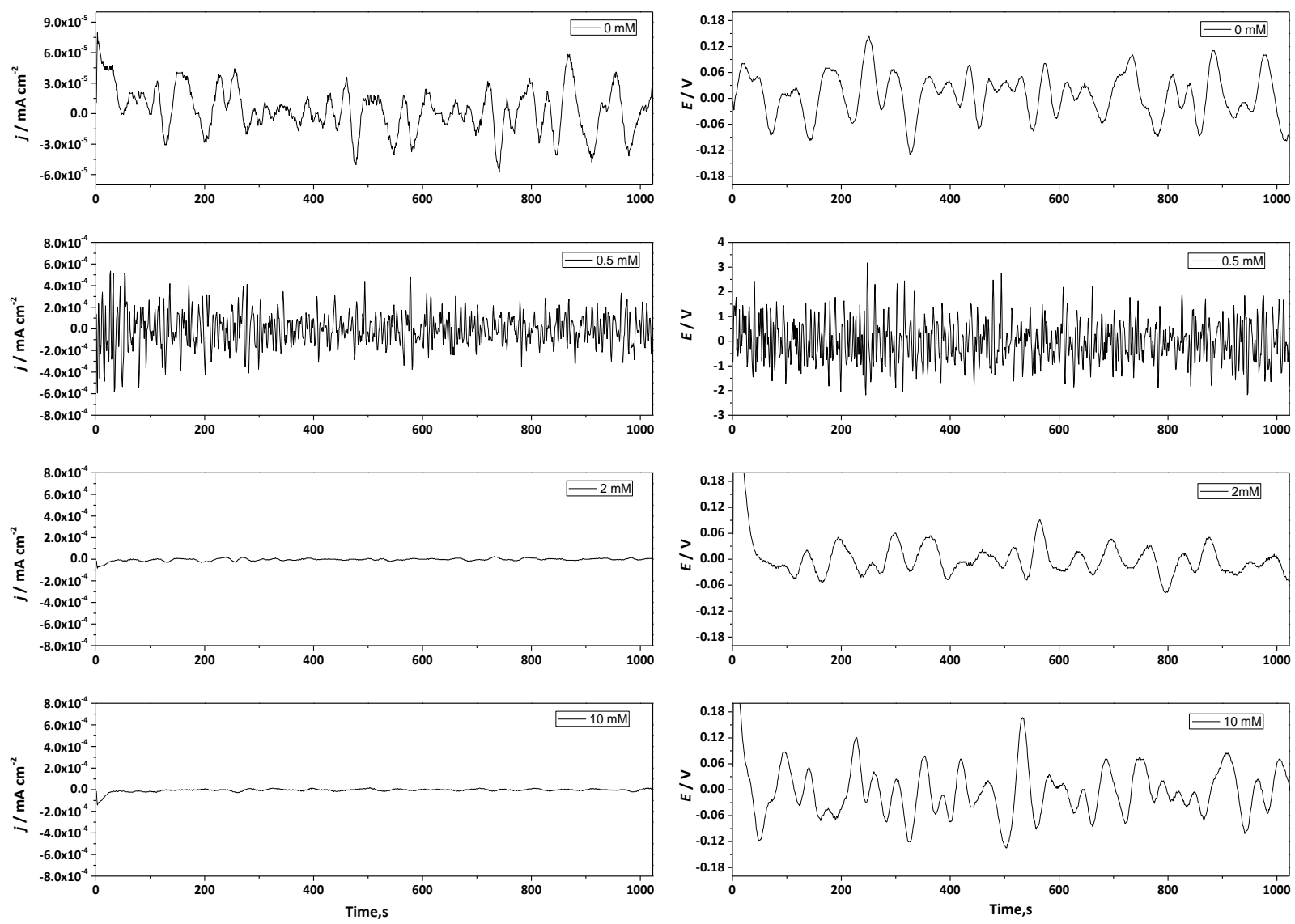

Figure 3. Time series of ECN (left) and EPN (right) for AA2024-T3-CFRP in galvanic couple immersed in 0.05 $\mathrm{M} \mathrm{NaCl}$ without and with 0.5-10 $\mathrm{mM} \mathrm{C}_{2} \mathrm{H}_{3} \mathrm{~N}_{3}$ at the beginning of the test (1 h) 
AA2024-T3 is highly susceptible to pitting corrosion due to the existing intermetallic particles [15]. When CFRP is kept in contact with AA2024-T3, these species cause increased electrons flow between cathodic and anodic areas. Through the electrochemical noise analysis done, the noise resistance $\left(R_{\mathrm{n}}\right)$ was calculated by the ratio of standard deviations of the current and potential $\left(\sigma_{\mathrm{l}} / \sigma_{\mathrm{P}}\right)$ measured after $24 \mathrm{~h}$ and shown in Figure 5. The highest value of $R_{\mathrm{n}}$ of $8.27 \mathrm{k} \Omega \mathrm{cm}^{2}$ was obtained at $10 \mathrm{mM}$ of $\mathrm{C}_{2} \mathrm{H}_{3} \mathrm{~N}_{3}$ which remains almost constant until the end of the test. It is obvious that with addition and further increment of the inhibitor concentration in the solution, a decrement in the current fluctuation of the time series was recorded at the beginning of the test as shown in Figure 3, and kept almost constant until the end of the test (Figure 4). These suggest the almost constant corrosion resistance of AA2024T3-CFPR in a galvanic couple (Figure 5).
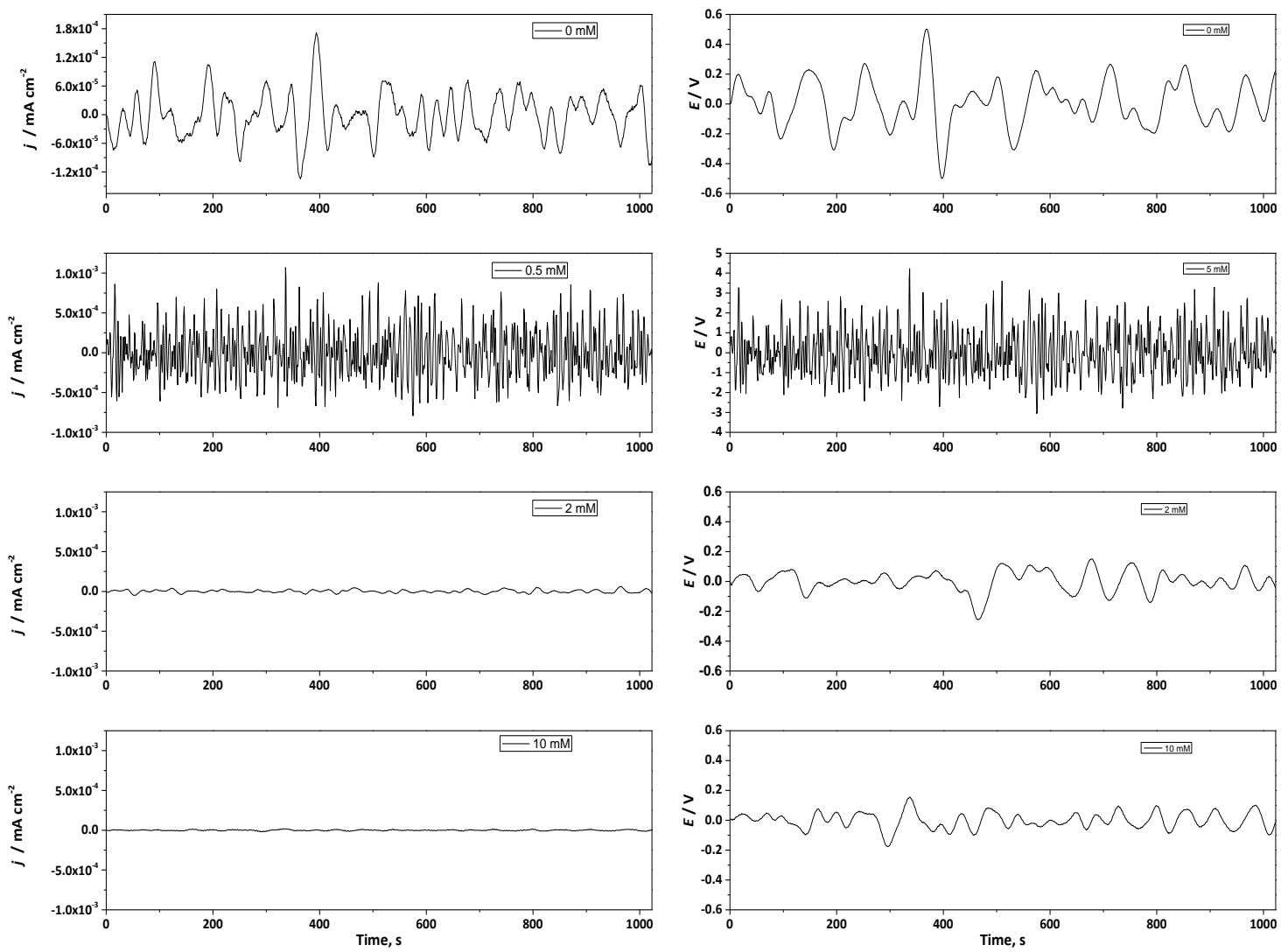

Figure 4. Time series of ECN (left) and EPN (right) for AA2024-T3-CFRP in galvanic couple immersed in 0.05 M NaCl without and with 0.5-10 $\mathrm{mM} \mathrm{C}_{2} \mathrm{H}_{3} \mathrm{~N}_{3}$ at the end of the test (24 h)

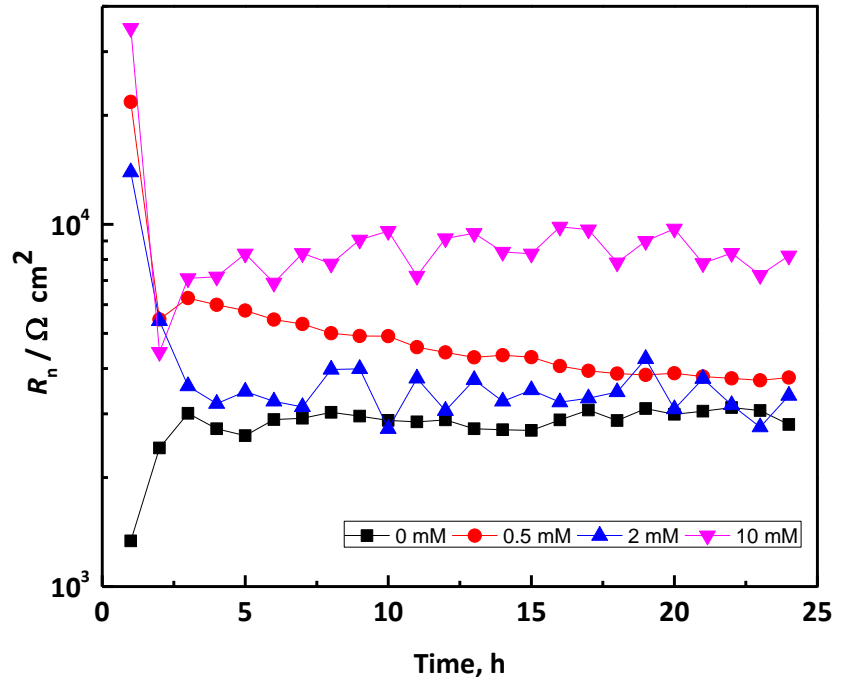

Figure 5. Time behavior of $R_{n}$ for $A A 2024-$ T3-CFRP in galvanic couple immersed in $0.05 \mathrm{M} \mathrm{NaCl}$ at different concentrations of $\mathrm{C}_{2} \mathrm{H}_{3} \mathrm{~N}_{3}$ 
The single exception in Figure 5 is observed at $0.5 \mathrm{mM} \mathrm{C}_{2} \mathrm{H}_{3} \mathrm{~N}_{3}$, where $R_{\mathrm{n}}$ tends to decrease due to the accelerated degradation of the surface, which forms a passive film susceptible to metastable pitting.

The power spectral density (PSD) plots represent the potential and current fluctuations of ENA over time as functions of frequency, allowing to determine energy changes in the system and the stability of a passive film formed over the metal surface.

When an increment in current is observed, the mass transport increases too, and when the potential increases, corrosion over the metal surface increases also. PSD plots for AA2024-T3-CFPR with and without $\mathrm{C}_{2} \mathrm{H}_{3} \mathrm{~N}_{3}$ are shown in Figure 6. PSD plots for the current at the beginning and the end of the test (Figure 6a and $6 \mathrm{c}$ ) did not show significant changes. At both testing times, the current density increased with the addition of $0.5 \mathrm{mM} \mathrm{C}_{2} \mathrm{H}_{3} \mathrm{~N}_{3}$ into the solution, which accelerates the mass transport phenomena from the bulk to the metallic surface and increases the exposed area due to the formation of porosities at the surface [16]. Moreover, PSD plots for the potential (Figure 6b and $6 \mathrm{~d})$ showed increments at $0.5 \mathrm{mM} \mathrm{C}_{2} \mathrm{H}_{3} \mathrm{~N}_{3}$, indicating rising corrosion over the metallic surface. For all the remainder concentrations, all is kept constant until the end of the test.
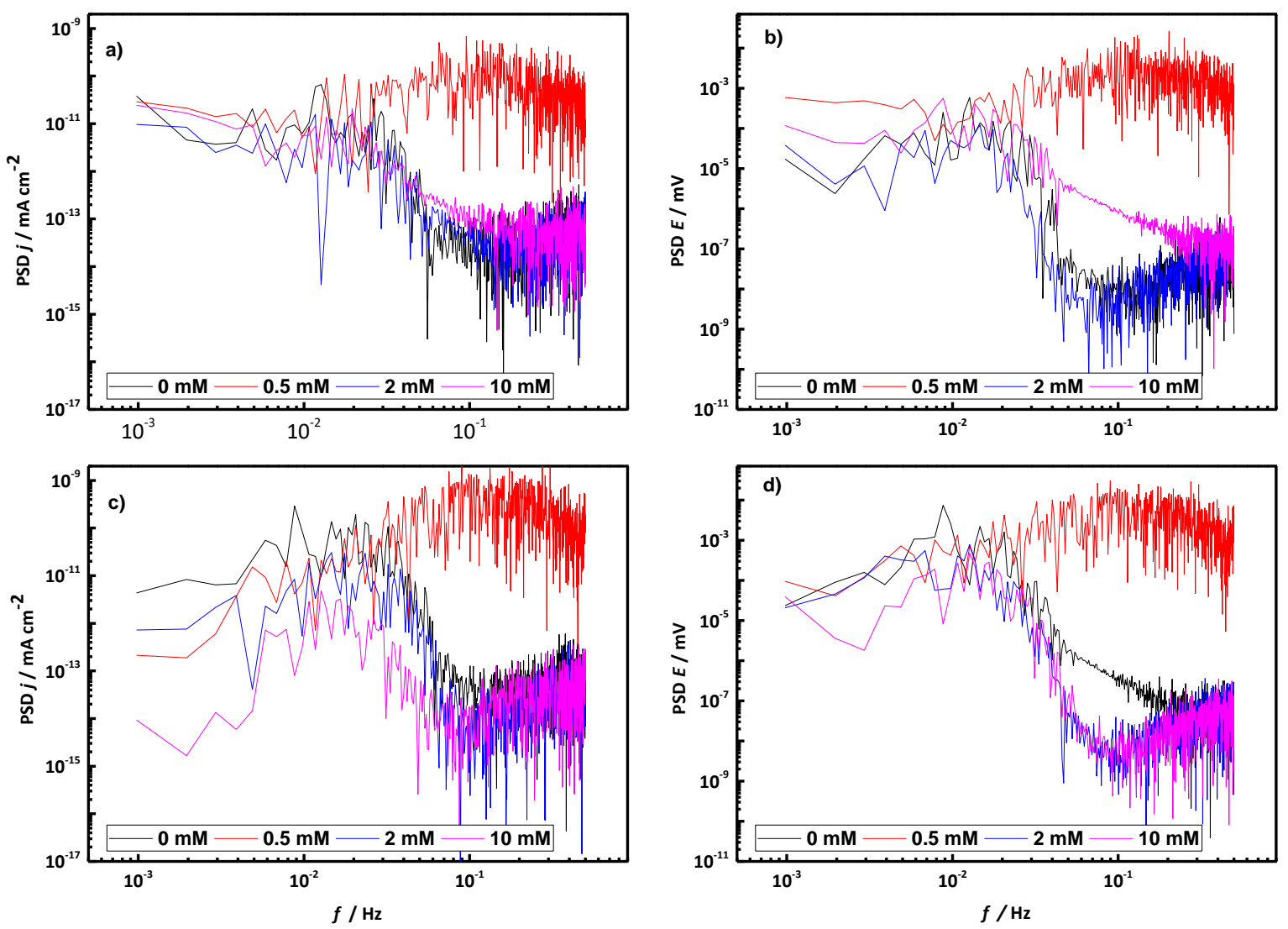

Figure 6. PSD plots of current (left) and potential (right) for AA2024-T3-CFRP in galvanic couple immersed in $0.05 \mathrm{M} \mathrm{NaCl}$ without and with 0.5-10 $\mathrm{mM} \mathrm{C}_{2} \mathrm{H}_{3} \mathrm{~N}_{3}$ at the beginning ( $a$ and $b$ ) and the end ( $c$ and $d$ ) of the test

Inhibition effect of cerium nitrate

Time series of current and potential noise fluctuations for AA2024-T3-CFRP immersed in $0.05 \mathrm{M}$ $\mathrm{NaCl}$ with and without $\mathrm{Ce}\left(\mathrm{NO}_{3}\right)_{3} \cdot 6 \mathrm{H}_{2} \mathrm{O}$ as corrosion inhibitor are shown in Figure 7 . At the beginning of the test $(1 \mathrm{~h})$, the addition of $\mathrm{Ce}\left(\mathrm{NO}_{3}\right)_{3} \cdot 6 \mathrm{H}_{2} \mathrm{O}$ generated an increment in the current and potential fluctuations (Figure 7), accelerating the corrosion process at the metal surface, and forming a passive layer of corrosion products. At the end of the measurement $(24 \mathrm{~h})$, this layer promotes a magnitude decrement of current fluctuations from $10^{-4}$ to $10^{-6} \mathrm{~mA} / \mathrm{cm}^{2}$, which was lower than the test without inhibitor (Figure 8). 

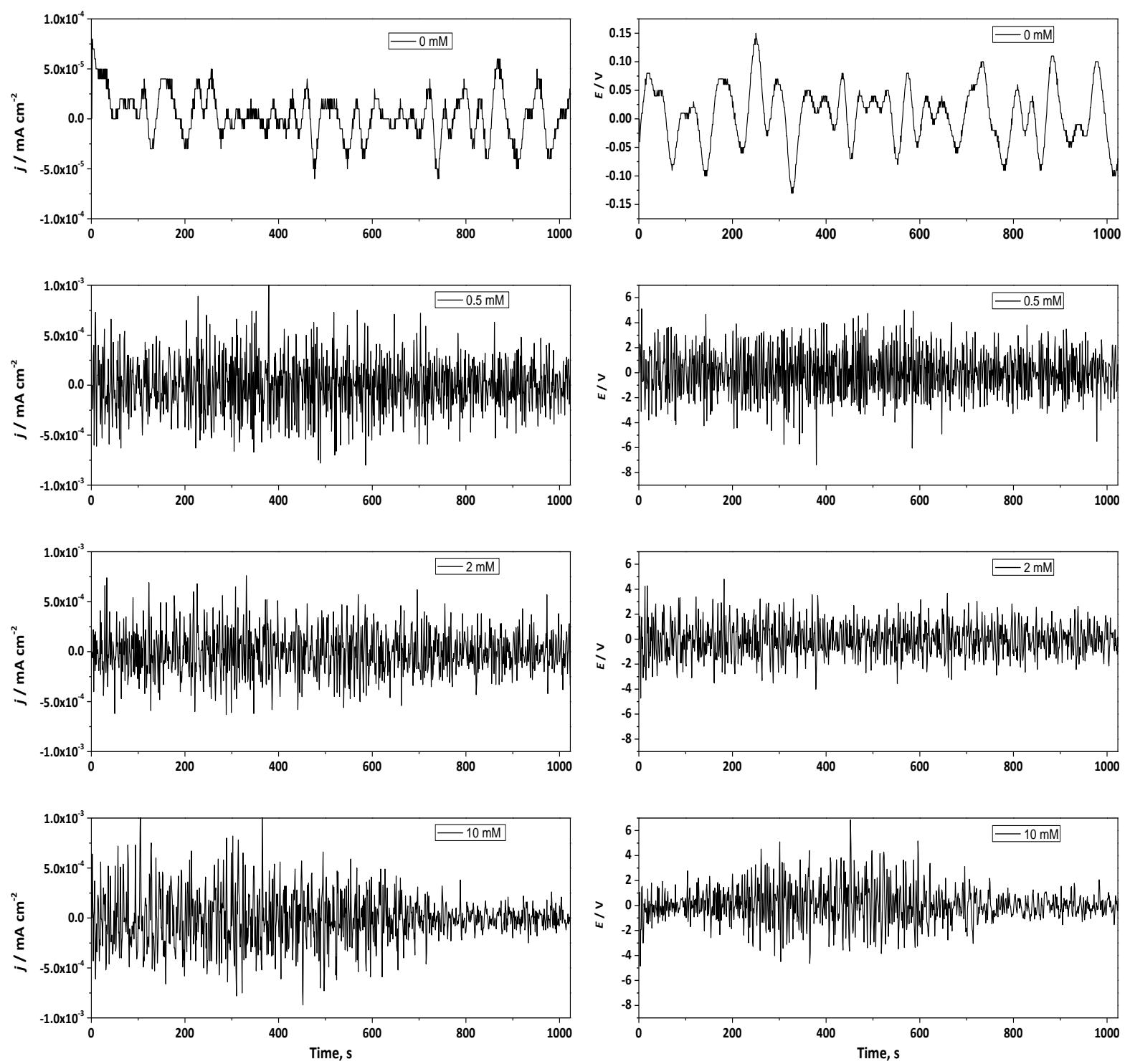

Figure 7. Time series of ECN (left) and EPN (right) for AA2024-T3-CFRP in galvanic couple immersed in $0.05 \mathrm{M} \mathrm{NaCl}$ without and with $0.5-10 \mathrm{mM} \mathrm{Ce}\left(\mathrm{NO}_{3}\right)_{3} \cdot 6 \mathrm{H}_{2} \mathrm{O}$ at the beginning of the test $(1 \mathrm{~h})$

The potential time series showed a decrement in intensity fluctuations from the beginning to the end of the test and also sudden potential drops and recovery transients with high amplitude and high frequency, typical of localized corrosion [17]. In the presence of the inhibitor, $R_{\mathrm{n}}$ values presented in Figure 9 showed a clear trend of increase with time of exposure and significant increment with the addition of $\mathrm{Ce}\left(\mathrm{NO}_{3}\right)_{3} \cdot 6 \mathrm{H}_{2} \mathrm{O}$ into the solution. The highest value of $R_{\mathrm{n}}$ was obtained for $0.5 \mathrm{mM} \mathrm{Ce}\left(\mathrm{NO}_{3}\right)_{3} \cdot 6 \mathrm{H}_{2} \mathrm{O}$, reaching $29.9 \times 10^{4} \Omega \mathrm{cm}^{2}$, which is at least one order of magnitude higher than without inhibitor $\left(2.77 \mathrm{k} \Omega \mathrm{cm}^{2}\right)$.

During the first hour, PSD for the current density showed an increment in the current density due to the mass transport phenomena (Figure 10. a), while PSD for the potential showed an increment correlated with the corrosion magnitude (Figure 10.10b). At the end of the test, PSD values for the current density and potential (Figure 10.10c and 10d) dropped slightly, suggesting improvement of the corrosion resistance of AA2024-T3-CFRP due to the formation of a passive film with high susceptibility to pitting corrosion.

Based on the fluctuations observed in Figures 3, 4, 7 and 8 for the time series for the current and potential, it was possible to determine that mixed corrosion (uniform type of corrosion combined with localized corrosion) is present over the metal surface of AA2024. The PSD for both inhibitors at the 
beginning of the test had an increment in the current density and potential, the first one is due to a rise in the mass transport and the second one suggests an increment in the corrosion process.
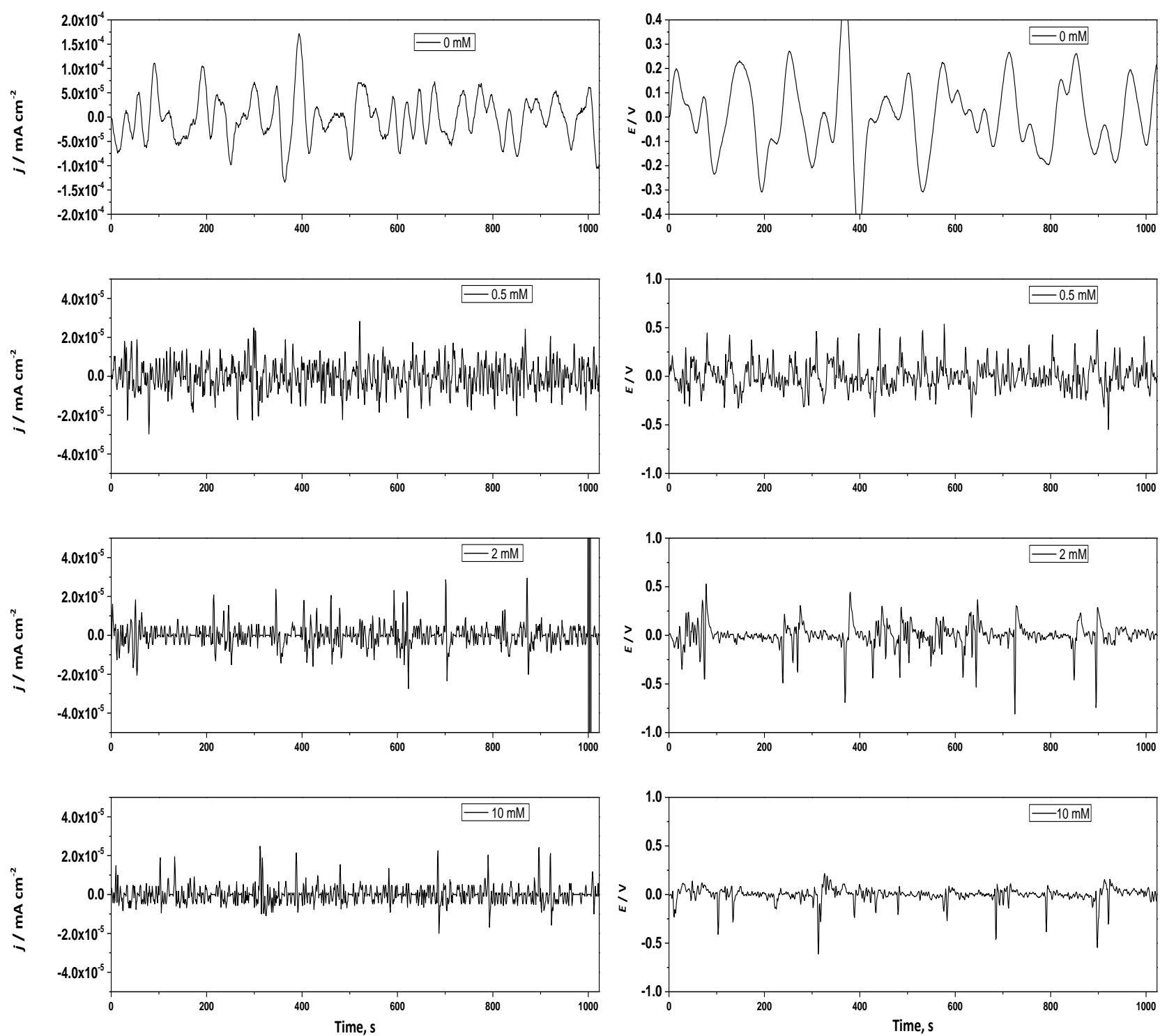

Figure 8. Time series of ECN (left) and EPN (right) for AA2024-T3-CFRP in galvanic couple immersed in $0.05 \mathrm{M} \mathrm{NaCl}$ without and with $0.5-10 \mathrm{mM} \mathrm{Ce}\left(\mathrm{NO}_{3}\right)_{3} \cdot 6 \mathrm{H}_{2} \mathrm{O}$ at the end of the test (24 h)

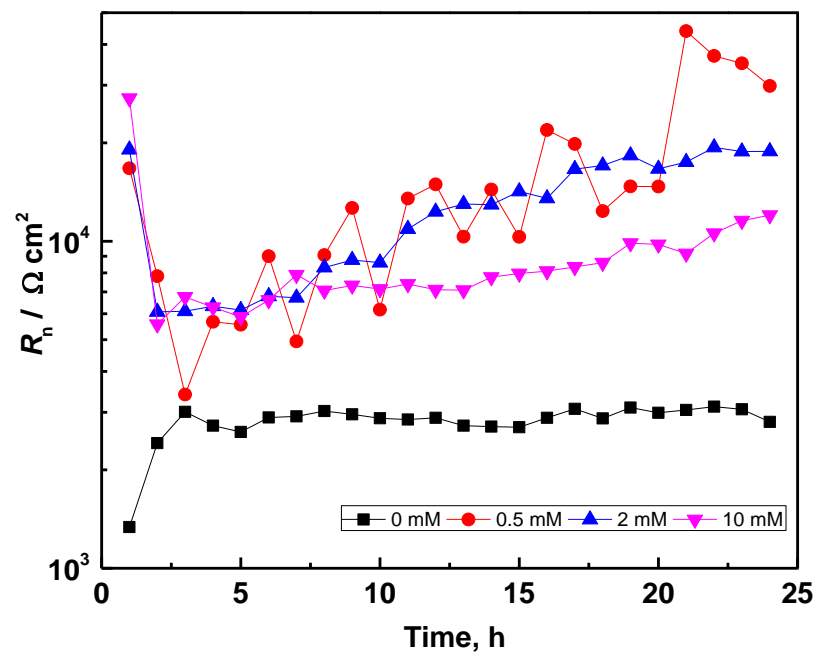

Figure 9. Time behavior of $R_{n}$ for AA2024-T3-CFRP in galvanic couple immersed in $0.05 \mathrm{M} \mathrm{NaCl}$ with different concentrations of $\mathrm{Ce}\left(\mathrm{NO}_{3}\right)_{3} \cdot 6 \mathrm{H}_{2} \mathrm{O}$ 

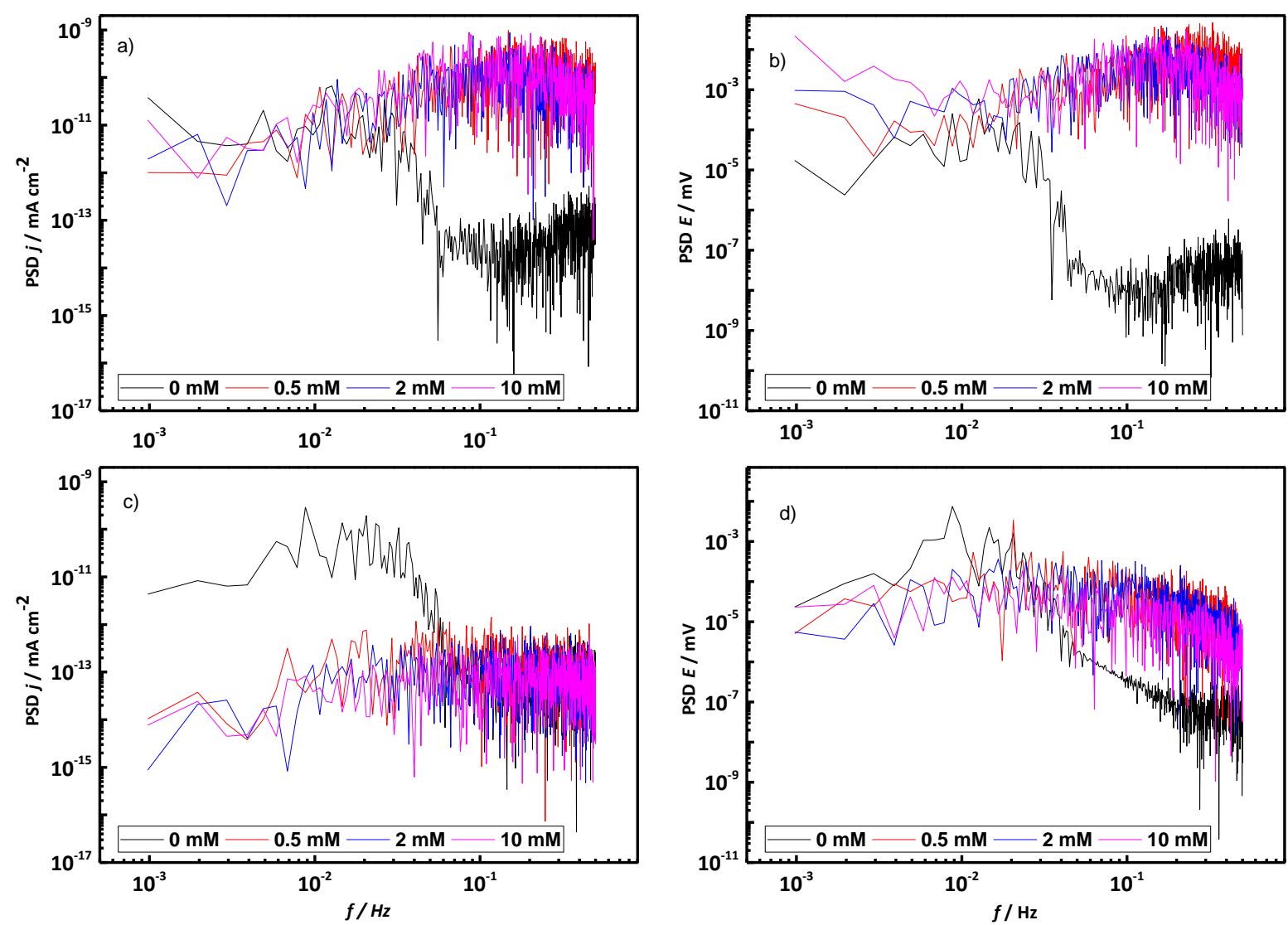

Figure 10. PSD of current (left) and potential (right) for AA2024-CFRP in galvanic couple immersed in $0.05 \mathrm{M} \mathrm{NaCl}$ without and with 0.5-10 $\mathrm{mM} \mathrm{Ce}\left(\mathrm{NO}_{3}\right)_{3} \cdot 6 \mathrm{H}_{2} \mathrm{O}$ at the beginning (a and b) and the end ( $c$ and d) of test

\section{EIS measurements}

Figure 11. shows Nyquist and Bode's plots recorded for AA2024-T3-CFRP in galvanic couple immersed in $0.05 \mathrm{M} \mathrm{NaCl}$ with and without $\mathrm{C}_{2} \mathrm{H}_{3} \mathrm{~N}_{3}$. Nyquist plots in Figure 11a showed the formation of a depressed semicircle at high to middle frequencies for all tests, which is usually attributed to the charge transfer phenomena. In addition, from middle to low frequencies, a second semicircle was recorded for each test, except at $0.5 \mathrm{mM} \mathrm{C}_{2} \mathrm{H}_{3} \mathrm{~N}_{3}$, which can be associated with the corrosion process at the metal surface. For solution without inhibitor and $0.5 m \mathrm{~m} \mathrm{C}_{2} \mathrm{H}_{3} \mathrm{~N}_{3}$, an inductive response is indicated at the lowest frequencies, usually related to intermediate adsorption/desorption and/or pitting corrosion.
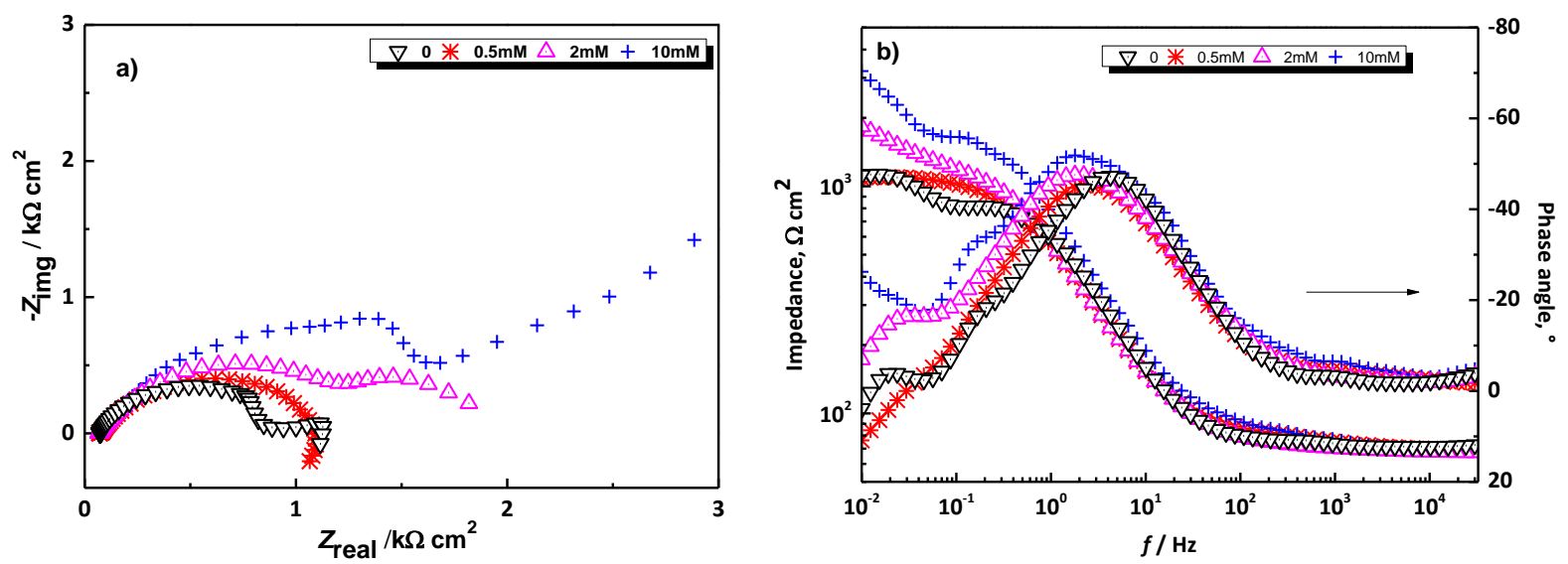

Figure 11. Nyquist (a) and Bode (b) plots for AA2024-T3-CFRP galvanic couple immersed for $24 \mathrm{~h}$ in $0.05 \mathrm{M} \mathrm{NaCl}$ without and with different concentrations of $\mathrm{C}_{2} \mathrm{H}_{3} \mathrm{~N}_{3}$ 
The impedance modulus values of Bode plots shown in Figure 11b increased gradually when $\mathrm{C}_{2} \mathrm{H}_{3} \mathrm{~N}_{3}$ was added into the solution, reaching the highest value at $10 \mathrm{mM} \mathrm{C}_{2} \mathrm{H}_{3} \mathrm{~N}_{3}$. Each phase angle plot of the galvanic couple presented in Figure $11 \mathrm{~b}$ exhibits one well-defined time constant about 2 $\mathrm{Hz}$, and one barely seen at about $1000 \mathrm{~Hz}$. The high-frequency time constant can be associated with the presence of a native oxide layer over the metallic surface [18], while this at about $2 \mathrm{~Hz}$ to the intermediate layer of corrosion products, including a thin layer of inhibitor molecules adsorbed over the surface. At frequencies lower than $0.1 \mathrm{~Hz}$, another time constant is present. Phenomena at the lowest frequencies are usually ascribed to the corrosion process at the substrate.

Figure 12. shows EIS spectra recorded for AA2024-T3-CFRP in galvanic couple exposed to $0.05 \mathrm{M}$ $\mathrm{NaCl}$ without and with different concentrations of $\mathrm{Ce}\left(\mathrm{NO}_{3}\right)_{3} \cdot 6 \mathrm{H}_{2} \mathrm{O}$. It can be noticed that when $\mathrm{Ce}\left(\mathrm{NO}_{3}\right)_{3} .6 \mathrm{H}_{2} \mathrm{O}$ was added into the solution, an increment in the impedance of the system occurs, particularly in the range of low frequencies, reaching its maximum value at $2 \mathrm{mM} \mathrm{Ce}\left(\mathrm{NO}_{3}\right)_{3} \cdot 6 \mathrm{H}_{2} \mathrm{O}$. In the phase angle spectra, it is possible to observe the formation of two-time constants at middle and low frequencies (Figure 12b). As was previously explained, the first-time constant could be related to the formation of a passive layer of corrosion products over the metal surface, including a thin layer of inhibitor over it. The low frequency related constant phase angle and clear inductive response at $0.5 \mathrm{mM}$ of $\mathrm{Ce}\left(\mathrm{NO}_{3}\right)_{3} \cdot 6 \mathrm{H}_{2} \mathrm{O}$ could be attributed to the corrosion process, which evidently changes with the concentration of inhibitor used for each test.

Several studies have already been done to establish the mechanism of corrosion in the presence of $\mathrm{Ce}\left(\mathrm{NO}_{3}\right)_{3} \cdot 6 \mathrm{H}_{2} \mathrm{O}$ as an inhibitor. In this way, it has been found that $\mathrm{Ce}\left(\mathrm{NO}_{3}\right)_{3} \cdot 6 \mathrm{H}_{2} \mathrm{O}$ acts as a cathodic inhibitor, blocking the occupied zones by intermetallic particles [19], preferentially in areas rich in copper, which has more cathodic potential with respect to the matrix [20].
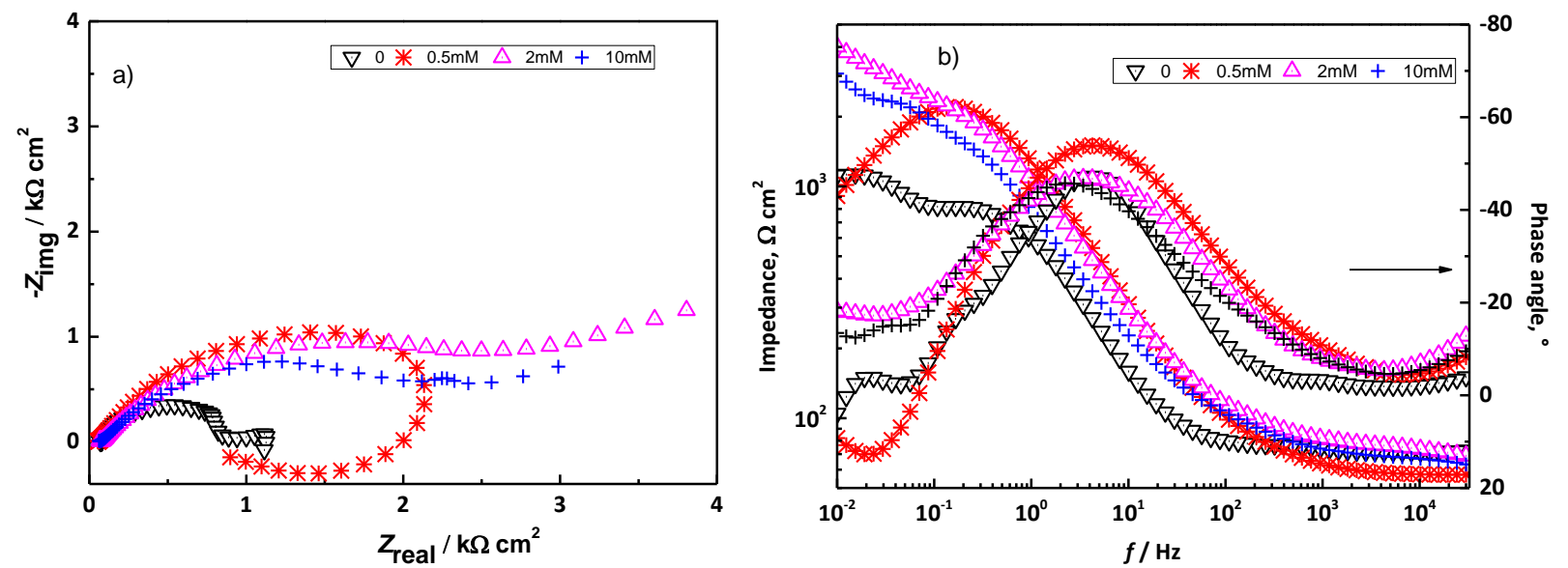

Figure 12. Nyquist (a) and Bode (b) plots for AA2024-T3-CFRP galvanic couple immersed for 24 $h$ in $0.05 \mathrm{M} \mathrm{NaCl}$ without and with different concentrations of $\mathrm{Ce}\left(\mathrm{NO}_{3}\right)_{3} \cdot 6 \mathrm{H}_{2} \mathrm{O}$

A mix of the optimal concentrations of $\mathrm{C}_{2} \mathrm{H}_{3} \mathrm{~N}_{3}(10 \mathrm{mM})$ and $\mathrm{Ce}\left(\mathrm{NO}_{3}\right)_{3} .6 \mathrm{H}_{2} \mathrm{O}(2 \mathrm{mM})$ was carried out to observe the effect of both inhibitors in a possible synergistic combination. The corresponding EIS spectra are presented in Figure 13. A significant increment of the semicircle diameter (Figure 13a) and impedance magnitude (Figure 13b) can be observed, which were both higher than for two inhibitors looking separately. This improvement of protection ability can be attributed to the fact that $\mathrm{Ce}\left(\mathrm{NO}_{3}\right)_{3} \cdot 6 \mathrm{H}_{2} \mathrm{O}$ is added preferentially to intermetallic sites (cathodic zones) through a hydroxide film formed over them, whereas $\mathrm{C}_{2} \mathrm{H}_{3} \mathrm{~N}_{3}$ is adsorbed over the aluminum matrix due to its polar groups, combined with double bonds in its structure, offering more stability to the film adsorbed over the metal surface. Based on the latter, it seems that each inhibitor enhanced the 
other's inhibition efficiency, reducing microgalvanic effects that promote localized attacks around the matrix, delaying the cathodic and anodic reactions.
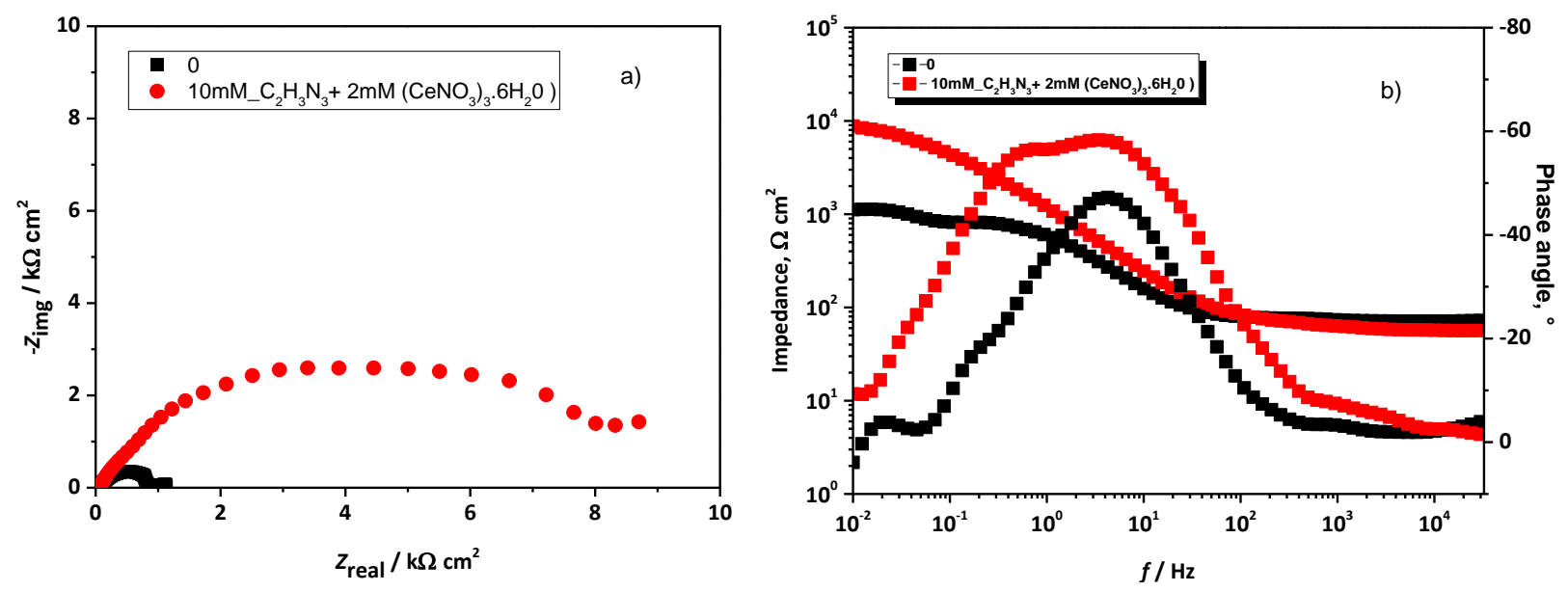

Figure 13. Nyquist (a) and Bode (b) plots for AA2024-T3-CFRP galvanic couple immersed for 24 $h$ in $0.05 \mathrm{M} \mathrm{NaCl}$ without and with $10 \mathrm{mM}$ of $\mathrm{C}_{2} \mathrm{H}_{3} \mathrm{~N}_{3}+2 \mathrm{mM} \mathrm{Ce}\left(\mathrm{NO}_{3}\right)_{3} \cdot 6 \mathrm{H}_{2} \mathrm{O}$

\section{Electrical equivalent circuit}

To simulate EIS data measured for AA2024-T3-CFRP in galvanic couple and evaluate polarization resistance $\left(R_{\mathrm{p}}\right)$ values, two electrical equivalent circuits were used for modeling (Figure 14). $R_{\mathrm{s}}$ is ascribed to the uncompensated solution resistance, while CPE $\mathrm{dl}_{\mathrm{dl}}$ and $R_{\mathrm{ct}}$ are the constant phase element of double layer and charge transfer resistance, respectively. $\mathrm{CPE}_{\text {inh+oxy }}$ is the constant phase element related to the film formed by corrosion products and adsorbed inhibitor, whereas $R_{\text {inh+oxy }}$ is ascribed to the corresponding surface film resistance.

a)

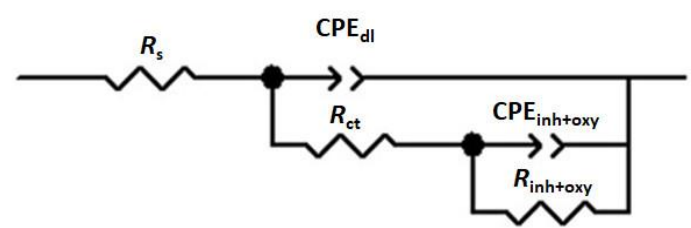

b)

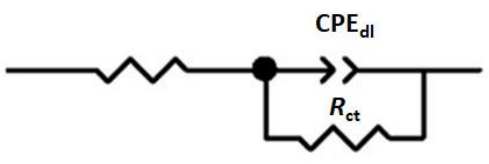

Figure 14. Electrical equivalent circuits used to fit EIS data for AA2024-T3-CFRP in galvanic couple immersed in $0.05 \mathrm{M} \mathrm{NaCl}$ in a) presence and b) absence of inhibitor

Table 2 summarizes $R_{\mathrm{p}}$ and IE values in solutions with and without $\mathrm{C}_{2} \mathrm{H}_{3} \mathrm{~N}_{3}, \mathrm{Ce}\left(\mathrm{NO}_{3}\right)_{3} \cdot 6 \mathrm{H}_{2} \mathrm{O}$ and their optimal concentrations mixture. All impedance parameter values, including $R_{\mathrm{ct}}$ and $R_{\text {inh+oxy, }}$ were obtained by fitting an electrical equivalent circuit in Figure 14 to measured impedance spectra (Figures 11-13). $R_{\mathrm{p}}$ was calculated as the sum of $R_{\mathrm{ct}}+R_{\mathrm{inh}+\mathrm{oxy}}[21]$.

Table 2. EIS-based polarization resistance $\left(R_{p}\right)$ and inhibition efficiency of $\mathrm{C}_{2} \mathrm{H}_{3} \mathrm{~N}_{3}, \mathrm{Ce}\left(\mathrm{NO}_{3}\right)_{3} \cdot 6 \mathrm{H}_{2} \mathrm{O}$ and their optimal concentrations mixture for AA2024-CFRP in galvanic couple immersed in $0.05 \mathrm{M} \mathrm{NaCl}$.

\begin{tabular}{|c|c|c|c|c|c|c|}
\hline Inhibitor & \multicolumn{2}{|c|}{$\mathrm{C}_{2} \mathrm{H}_{3} \mathrm{~N}_{3}$} & \multicolumn{2}{|c|}{$\mathrm{Ce}\left(\mathrm{NO}_{3}\right)_{3} \cdot 6 \mathrm{H}_{2} \mathrm{O}$} & \multicolumn{2}{|c|}{$\mathrm{C}_{2} \mathrm{H}_{3} \mathrm{~N}_{3}+\mathrm{Ce}\left(\mathrm{NO}_{3}\right)_{3} \cdot 6 \mathrm{H}_{2} \mathrm{O}$} \\
\hline$c_{\text {inh }} / \mathrm{mM}$ & $R_{\mathrm{p}} / \Omega \mathrm{cm}^{2}$ & $\mathrm{IE}, \%$ & $R_{\mathrm{p}} / \Omega \mathrm{cm}^{2}$ & $\mathrm{IE}, \%$ & $R_{\mathrm{p}} / \Omega \mathrm{cm}^{2}$ & $\mathrm{IE}, \%$ \\
\hline 0 & $9.90 \times 10^{2}$ & -- & $9.90 \times 10^{2}$ & -- & $9.90 \times 10^{2}$ & -- \\
\hline 0.5 & $1.12 \times 10^{3}$ & 11 & $2.54 \times 10^{3}$ & 61 & -- & -- \\
\hline 2 & $1.97 \times 10^{3}$ & 49 & $5.28 \times 10^{3}$ & 81 & \multirow{2}{*}{$8.36 \times 10^{3}$} & \multirow{2}{*}{88} \\
\hline 10 & $5.05 \times 10^{3}$ & 80 & $3.39 \times 10^{3}$ & 70 & & \\
\hline
\end{tabular}

The inhibition efficiency of the inhibitor was calculated using Eq (2), 


$$
\mathrm{IE}=\frac{R_{\mathrm{p} / \text { inh }}-R_{\mathrm{p} / \mathrm{o}}}{R_{\mathrm{p} / \text { inh }}} 100
$$

where $R_{\mathrm{p} / \mathrm{Inh}}$ and $R_{\mathrm{p} / 0}$ are polarization resistance $\left(R_{\mathrm{p}}\right)$ with and without inhibitor in the electrolyte.

The repeatability and reproducibility of $R_{\mathrm{p}}$ values at optimal concentrations for both inhibitors were determined by the standard deviation obtained after repeating the tests three times for each inhibitor. At $10 \mathrm{mM} \mathrm{C}_{2} \mathrm{H}_{3} \mathrm{~N}_{3}, R_{\mathrm{p}}$ was calculated as $5.05 \mathrm{k} \Omega \mathrm{cm}^{2}$ with the standard deviation of $\pm 47 \Omega$ $\mathrm{cm}^{2}$, while for $2 \mathrm{mM} \mathrm{Ce}\left(\mathrm{NO}_{3}\right)_{3} \cdot 6 \mathrm{H}_{2} \mathrm{O}, R_{\mathrm{p}}$ value of $5.28 \mathrm{k} \Omega \mathrm{cm}^{2}$ was estimated with the standard deviation of $\pm 699 \Omega \mathrm{cm}^{2}$.

Figures 15 and 16 compare $R_{\mathrm{n}}$ and $R_{\mathrm{p}}$ values obtained from ENA and EIS measurements, presenting them in dependence on concentrations of two inhibitors, showing seemingly close behavior between two resistances.

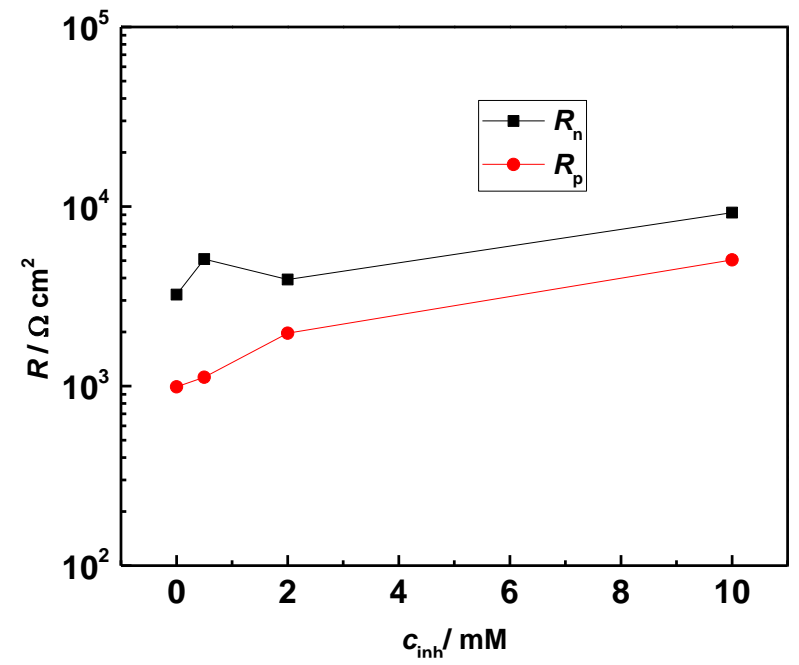

Figure 15. $R_{n}$ and $R_{P}$ values in dependence on the concentration $\mathrm{C}_{2} \mathrm{H}_{3} \mathrm{~N}_{3}$ inhibitor

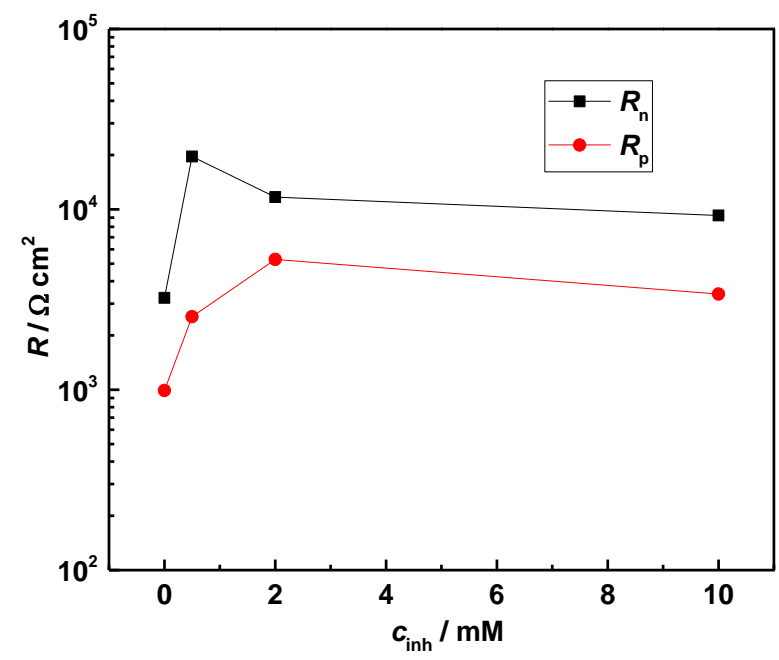

Figure 16. $R_{n}$ and $R_{P}$ values in dependence on the concentration of $\mathrm{Ce}\left(\mathrm{NO}_{3}\right)_{3} \cdot 6 \mathrm{H}_{2} \mathrm{O}$ inhibitor

\section{Characterization of inhibitor adsorption}

$R_{\mathrm{n}}$ and $R_{\mathrm{p}}$ values can be used to estimate the Gibbs free energy $\left(\Delta G^{\circ}\right.$ ads $)$, which is an indicator of the type of molecular interaction between the inhibitor and metal surface through the establishment adsorption isotherm model. For this, it is necessary to estimate the fractional surface coverage $(\theta)$ values, which would give an idea about the surface covered by an inhibitor. The values of $\theta$ were estimated by equation (2), and the results are listed in Table 3.

$$
\theta=\frac{R_{\mathrm{p}, \mathrm{n} / \mathrm{inh}}-R_{\mathrm{p}, \mathrm{n} / 0}}{R_{\mathrm{p}, \mathrm{n} / \mathrm{inh}}}
$$

Table 3. Fractional surface coverage $(\theta)$ for different concentrations of two corrosion inhibitors at AA2024-

T3-CFPR in a galvanic couple, calculated by $R_{n}$ and $R_{p}$ values obtained by EN and EIS analysis

\begin{tabular}{ccccc} 
& \multicolumn{5}{c}{$\theta$} & \multicolumn{3}{c}{$\mathrm{Ce}\left(\mathrm{NO}_{3}\right)_{3} .6 \mathrm{H}_{2} \mathrm{O}$} \\
\cline { 2 - 6 }$c_{\text {inh }} / \mathrm{mM}$ & \multicolumn{3}{c}{$\mathrm{C}_{2} \mathrm{H}_{3} \mathrm{~N}_{3}$} & \multicolumn{3}{c}{ Calculated by } \\
\cline { 2 - 6 } & $R_{\mathrm{n}}$ & $R_{\mathrm{p}}$ & $R_{\mathrm{n}}$ & $R_{\mathrm{p}}$ \\
\cline { 2 - 5 } & 0.37 & 0.12 & 0.84 & 0.61 \\
\hline 0.5 & 0.17 & 0.50 & 0.72 & 0.81 \\
\hline 2 & 0.65 & 0.80 & 0.65 & 0.71 \\
\hline 10 & & &
\end{tabular}

Langmuir and Temkin isotherms are defined by the equations (3) and (4),

$$
\frac{\theta}{1-\theta}=K c_{\text {inh }}
$$




$$
\log \frac{\theta}{c_{\text {inh }}}=\log K+\theta g
$$

where $K$ is equilibrium adsorption constant, $g$ is molecular interaction parameter, and $c_{\text {inh }}$ is the concentration of the inhibitor. By determining $K$ value, Gibbs free energy of adsorption can be calculated by equation (5):

$$
\Delta G^{\circ}{ }_{\text {ads }}=-R T \ln (55.5 K)
$$

where $R$ is gas constant, $T$ is the temperature in Kelvin grades, and 55.5 is the molar concentration of water in solution.

The interactions between the surface of AA2024-T3-CFRP in galvanic couple with either $\mathrm{C}_{2} \mathrm{H}_{3} \mathrm{~N}_{3}$ or $\mathrm{Ce}\left(\mathrm{NO}_{3}\right)_{3} \cdot 6 \mathrm{H}_{2} \mathrm{O}$ as corrosion inhibitors are best described by Langmuir isotherm in the first case and Temkin isotherm in the second case. The best-fitted results using models described by eqns. (3) and (4) are shown in Figures 17 and 18, respectively. The Langmuir model (Figure 17) assumes that there are sites with the capability to physically or chemically hold one molecule over the surface. All sites are equivalent and there are no interactions between molecules. The Temkin model (Figure 18) establishes a heterogeneous surface divided into zones, some of them without molecular interactions, establishing an attraction or repulsion of the inhibitor over the metal surface by zones.

The values of $\Delta G^{\circ}$ ads were calculated using $R_{\mathrm{n}}$ and $R_{\mathrm{p}}$ values reported in Table 3. Applying the eq. (5), values of $\Delta G^{\circ}$ ads of $\mathrm{C}_{2} \mathrm{H}_{3} \mathrm{~N}_{3}$ adsorption were calculated as $-35 \mathrm{~kJ} / \mathrm{mol}$ based on $R_{\mathrm{n}}$, and $-37 \mathrm{~kJ} / \mathrm{mol}$ based on $R_{\mathrm{p}}$. For $\mathrm{Ce}\left(\mathrm{NO}_{3}\right)_{3} \cdot 6 \mathrm{H}_{2} \mathrm{O}, \Delta G_{\text {ads }}^{\circ}$ of $-26.78 \mathrm{~kJ} / \mathrm{mol}$ based on $R_{\mathrm{n}}$, and $-26.89 \mathrm{~kJ} / \mathrm{mol}$ based on $R_{\mathrm{p}}$ were calculated. These $\Delta \mathrm{G}^{\circ}$ ads values suggest physisorption and chemisorption of both inhibitors over the metal surface, since values below $-20 \mathrm{~kJ} / \mathrm{mol}$ are indicative of physisorption, while values higher than $-40 \mathrm{~kJ} / \mathrm{mol}$ suggest chemisorption. The values between -20 and $-40 \mathrm{~kJ} / \mathrm{mol}$ as obtained here, are indicative of a combination of both physisorption and chemisorption. In addition, negative values of $\Delta G^{\circ}$ ads are indicative of spontaneous adsorption. The estimated values of Gibbs free energy establish the exothermic adsorption process, in agreement with Langmuir and Temkin isotherms for $\mathrm{C}_{2} \mathrm{H}_{3} \mathrm{~N}_{3}$ and $\mathrm{Ce}\left(\mathrm{NO}_{3}\right)_{3} \cdot 6 \mathrm{H}_{2} \mathrm{O}$, respectively. Negative values of $\Delta G^{\circ}$ ads values suggest that chemisorption and physisorption proceed the metallic surface as spontaneous processes.

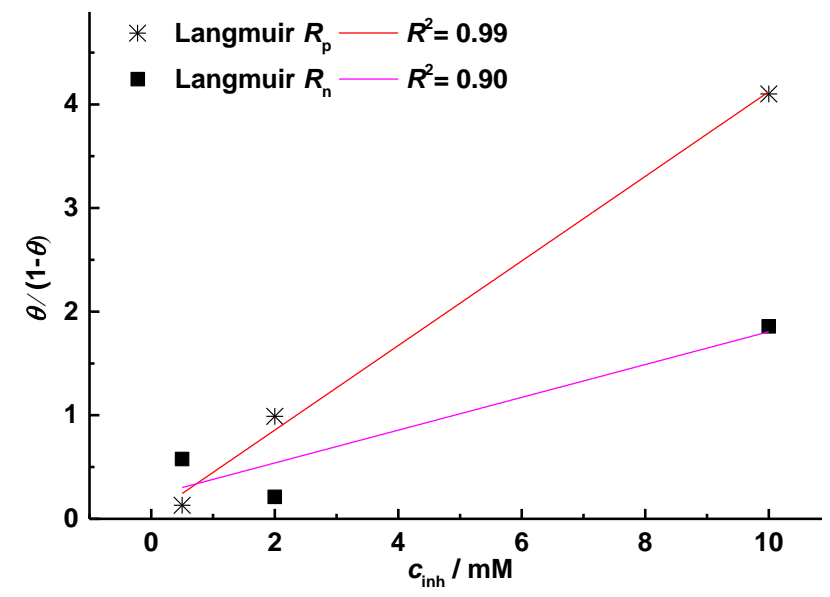

Figure 17. Langmuir isotherm for adsorption of $\mathrm{C}_{2} \mathrm{H}_{3} \mathrm{~N}_{3}$ inhibitor

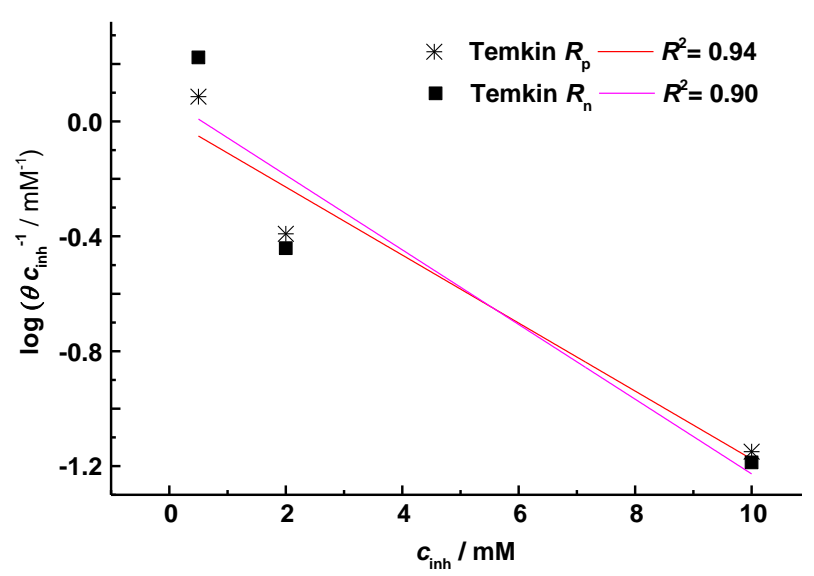

Figure 18. Temkin isotherm for adsorption of $\mathrm{Ce}\left(\mathrm{NO}_{3}\right)_{3} \cdot 6 \mathrm{H}_{2} \mathrm{O}$ inhibitor

\section{Surface analysis}

The scanning electron microscopy (SEM) allowed obtaining images of AA2024-T3 and CFRP surfaces. Figure 19 shows the surface of AA2024-T3 before and after its exposure for $24 \mathrm{~h}$ in the aggressive media containing $\mathrm{Ce}\left(\mathrm{NO}_{3}\right)_{3} \cdot 6 \mathrm{H}_{2} \mathrm{O}$. EDS analysis was also carried out before and after 
immersion of AA2024-T3 into $0.05 \mathrm{M} \mathrm{NaCl}$ (Figure 19). Corrosion products can be identified in places with $\mathrm{Cu}$ particles, as demonstrated in previous research [23]. $\mathrm{Ce}\left(\mathrm{NO}_{3}\right)_{3} \cdot 6 \mathrm{H}_{2} \mathrm{O}$ was preferentially deposited over cathodic regions. EDS analysis confirms the presence of rare-earth oxide deposition, as well as the formation of oxide film products.
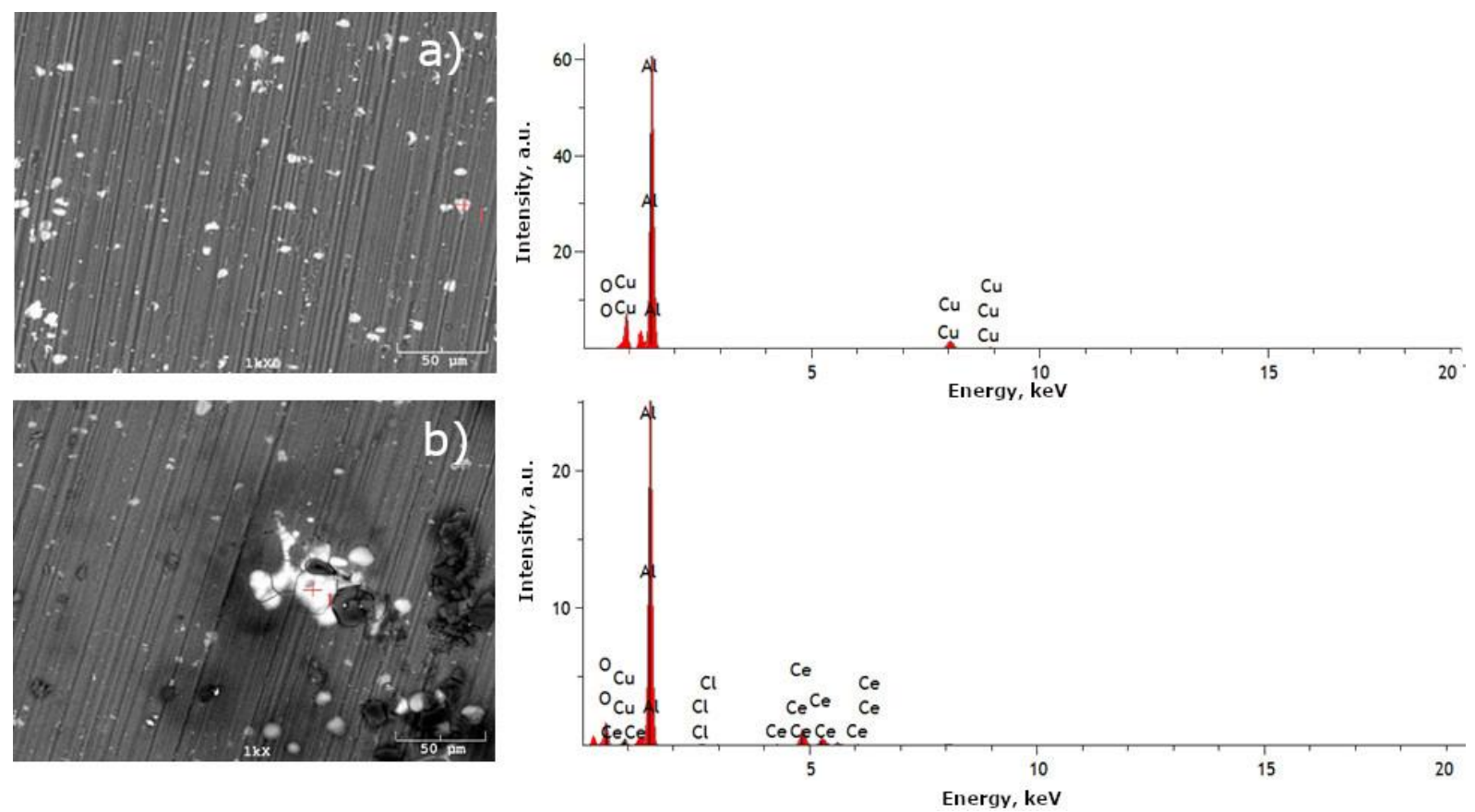

Figure 19. SEM micrographs and EDS analysis for aluminum alloy AA2024-T3 before a) and after b) exposure for $24 \mathrm{~h}$ in $0.05 \mathrm{M} \mathrm{NaCl}$ with $\mathrm{Ce}\left(\mathrm{NO}_{3}\right)_{3} \cdot 6 \mathrm{H}_{2} \mathrm{O}$ as a corrosion inhibitor

Figure 20 shows SEM micrographs taken for CFRP surface before and after it was immersed in the electrolyte with $\mathrm{Ce}\left(\mathrm{NO}_{3}\right)_{3} \cdot 6 \mathrm{H}_{2} \mathrm{O}$ as a corrosion inhibitor. The EDS analysis revealed the deposition of $\mathrm{Ce}\left(\mathrm{NO}_{3}\right)_{3} \cdot 6 \mathrm{H}_{2} \mathrm{O}$ and aluminum particles on its surface after it is immersed in the electrolyte, especially in the areas rich in carbon.
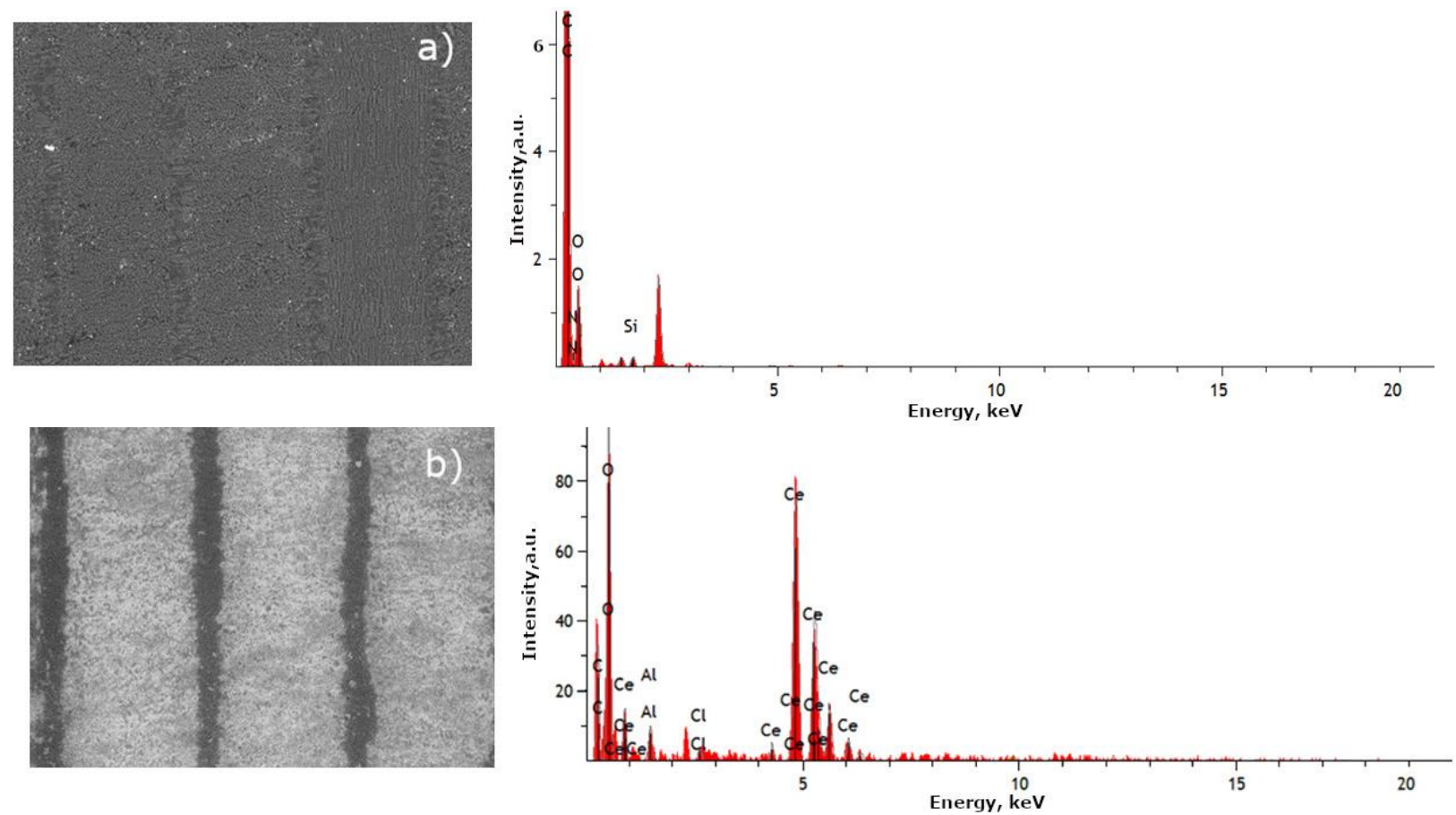

Figure 20. SEM micrographs and EDS analysis for CFRP before a) and after b) exposition for $24 \mathrm{~h}$ to $0.05 \mathrm{M} \mathrm{NaCl}$ with $\mathrm{Ce}\left(\mathrm{NO}_{3}\right)_{3} \cdot 6 \mathrm{H}_{2} \mathrm{O}$ as a corrosion inhibitor 


\section{Conclusion}

The inhibition effect against the galvanic corrosion effect between the aluminum alloy 2024-T3 and CFRP immersed in $0.05 \mathrm{M} \mathrm{NaCl}$ was evaluated at different concentrations $(0.5,2,10 \mathrm{mM})$ of inorganic $\left(\mathrm{Ce}\left(\mathrm{NO}_{3}\right)_{3} \cdot 6 \mathrm{H}_{2} \mathrm{O}\right)$ and organic $\left(\mathrm{C}_{2} \mathrm{H}_{3} \mathrm{~N}_{3}\right)$ compounds. The polarization resistance $\left(R_{\mathrm{p}}\right)$ measured using EIS for AA2024-CFRP galvanic couple increased slightly in the presence of $\mathrm{C}_{2} \mathrm{H}_{3} \mathrm{~N}_{3}$, reaching its maximum efficiency at $10 \mathrm{mM}$ with $80 \%$ of inhibition efficiency. $\mathrm{Ce}\left(\mathrm{NO}_{3}\right)_{3} \cdot 6 \mathrm{H}_{2} \mathrm{O}$ showed the highest polarization resistance at a lower concentration of $2 \mathrm{mM}$, with $81 \%$ inhibition efficiency. For a mix of optimal concentrations of $\mathrm{C}_{2} \mathrm{H}_{3} \mathrm{~N}_{3}$ and $\mathrm{Ce}\left(\mathrm{NO}_{3}\right)_{3}{ }_{3} 6 \mathrm{H}_{2} \mathrm{O}, R_{\mathrm{p}}$ of $8.36 \mathrm{k} \Omega \mathrm{cm}^{2} \pm 243 \Omega \mathrm{cm}^{2}$ was measured, suggesting a synergistic effect of these two inhibitors in enhancing corrosion protection. Similar behavior was observed for the noise resistance $\left(R_{\mathrm{n}}\right)$ obtained using ENA, where $\mathrm{Ce}\left(\mathrm{NO}_{3}\right)_{3} \cdot 6 \mathrm{H}_{2} \mathrm{O}$ showed higher resistance than $\mathrm{C}_{2} \mathrm{H}_{3} \mathrm{~N}_{3}$. Free energy of adsorption $\Delta G^{\circ}$ ads was calculated using $R_{\mathrm{n}}$ and $R_{\mathrm{p}}$ values obtained by ENA and EIS analysis, respectively. $\Delta G^{\circ}$ ads values of $35 \mathrm{~kJ} / \mathrm{mol}$ for $R_{\mathrm{n}}$ and $-37 \mathrm{~kJ} / \mathrm{mol}$ for $R_{\mathrm{p}}$ were calculated for $\mathrm{C}_{2} \mathrm{H}_{3} \mathrm{~N}_{3}$, while for $\mathrm{Ce}\left(\mathrm{NO}_{3}\right)_{3} \cdot 6 \mathrm{H}_{2} \mathrm{O},-26.78$ $\mathrm{kJ} / \mathrm{mol}$ for $R_{\mathrm{n}}$ and $-26.89 \mathrm{~kJ} / \mathrm{mol}$ for $R_{\mathrm{p}}$ were obtained. These $\Delta G^{\circ}$ ads values suggest chemisorption and physisorption of both inhibitors over the metal surface.

Acknowledgement: This work was supported by grant agreement 270252/232335 from CONACYT.

\section{References}

[1] R. Alderliesten, R. Benedictus, Journal of Aircraft 45(4) (2008) 1182-1189.

https://doi.org/10.2514/1.33946

[2] T. Sinmazçelik, E. Avcu, M. Ö. Bora, O. Çoban, Materials \& Design 32(7) (2011) 3671-3685. http://dx.doi.org/10.1016/i.matdes.2011.03.011

[3] A. Pardo, M. C. Merino, A. E. Coy, R. Arrabal, F. Viejo, E. Matykina, Corrosion Science 50(3) (2008) 823-834. http://dx.doi.org/10.1016/j.corsci.2007.11.005

[4] G. Song, B. Johannesson, S. Hapugoda, D. StJohn, Corrosion Science 46(4) (2004) 955-977. http://dx.doi.org/10.1016/S0010-938X(03)00190-2

[5] Y. Pan, G. Wu, X. Cheng, Z. Zhang, M. Li, S. Ji, Z. Huang, Corrosion Science 98 (2015) 672-677. http://dx.doi.org/10.1016/i.corsci.2015.06.024

[6] M. Mokaddem, P. Volovitch, F. Rechou, R. Oltra, K. Ogle, Electrochimica Acta 55(11) (2010) 37793786. http://dx.doi.org/10.1016/j.electacta.2010.01.079

[7] E. Matter, S. Kozhukharov, M. Machkova, V. Kozhukharov, Scientific Papers of The University of Russia 48(9) (2009) 19-23. http://conf.uni-ruse.bg/bg/docs/cp09/9/9-3.pdf

[8] G. Wu, J. M. Yang, JOM 57(1) (2005) 72-79. https://doi.org/10.1007/s11837-005-0067-4

[9] L. Dong-xia, L. Li, L. Ming, IOP Conference Series: Materials Science and Engineering 10 (2010) 012098. http://dx.doi.org/10.1088/1757-899X/10/1/012098

[10] D. Liu, Y. Tang, W. L. Cong, Composite Structures 94(4) (2012) 1265-1279. http://dx.doi.org/10.1016/i.compstruct.2011.11.024

[11] S. Payan, Y. Le Petitcorps, J. M. Olive, H. Saadaoui, Composites Part A: Applied Science and Manufacturing 32(3-4) (2001) 585-589. http://dx.doi.org/10.1016/S1359-835X(00)00126-3

[12] El-Sayed M. Sherif, F. H. Latif, H. Junaedi, International Journal of Electrochemical Science 6 (2011) 1085-1099. http://www.electrochemsci.org/papers/vol6/6041085.pdf

[13] W.-X. Wang, Y. Takao, T. Matsubara, Proceedings of the $16^{\text {th }}$ International Conference on Composite Materials, ICCM-16, (2007) 1-10. https://www.iccm-central.org/Proceedings/ICCM16proceedings/ contents/pdf/WedK/WeKM1-05ge wangw224701p.pdf

[14] V. Palanivel, Y. Huang, W. J. van Ooij, Progress in Organic Coatings 53(2) (2005) 153-168. http://dx.doi.org/10.1016/i.porgcoat.2003.07.008

[15] C.-M. Liao, R. P. Wei, Electrochimica Acta 45(6) (1999) 881-888. http://dx.doi.org/10.1016/S00134686(99)00299-6

[16] C. Monticelli, F. Zucchi, G. Brunoro, G. Trabanelli, Journal of Applied Electrochemistry 27 (1997) 325334. https://doi.org/10.1023/A:1018436931465 
[17] A. Torres, J. Uruchurtu, J. G. González-Rodríguez, S. Serna, Corrosion (Houston) 63(9) (2007) 866871. http://dx.doi.org/10.5006/1.3278437

[18] M. L. Zheludkevich, K. A. Yasakau, S. K. Poznyak, M. G. S. Ferreira, Corrosion Science 47(12) (2005) 3368-3383. http://dx.doi.org/10.1016/j.corsci.2005.05.040

[19] A. Aballe, M. Bethencourt, F. J. Botana, M. J. Cano, M. Marcos, Materials and Corrosion 52(5) (2001) 344-350. https://doi.org/10.1002/1521-4176(200105)52:5\%3C344::AID-MACO344\%3E3.0.CO;2-S

[20] A. Decroly, J.-P. Petitjean, Surface and Coatings Technology 194(1) (2005) 1-9. http://dx.doi.org/ 10.1016/j. surfcoat.2004.05.012.

[21] A. Salve, V. Kozhukharov, J. Pernas, E. Matter, M. Machkova, Journal of University of Chemical Technology and Metallurgy 47(3) (2012) 319-328. https://www.researchgate.net/publication/ $\underline{268002945}$

[22] S. Kozhukharov, V. Kozhukharov, M. Wittmar, M. Schem, M. Aslan, H. Caparrotti, M. Veith, Progress in Organic Coatings 71(2) (2011) 198-205. https://doi.org/10.1016/i.porgcoat.2011.02.013

[23] M. L. Zheludkevich, R. Serra, M. F. Montemor, K. A. Yasakau, I. M. M. Salvado, M. G. S. Ferreira, Electrochimica Acta 51(2) (2005) 208-217. https://doi.org/10.1016/j.electacta.2005.04.021

(C)2021 by the authors; licensee IAPC, Zagreb, Croatia. This article is an open-access article distributed under the terms and conditions of the Creative Commons Attribution license (https://creativecommons.org/licenses/by/4.0/) 